\title{
Intergenerational transmission and organised crime. A study of seven families in the south of the Netherlands
}

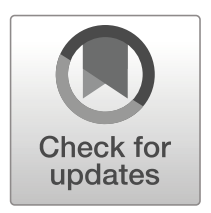

\author{
Toine Spapens $^{1}$ (D) $\cdot$ Hans Moors ${ }^{2}$
}

Published online: 19 March 2019

(C) The Author(s) 2019

\begin{abstract}
Kinship ties play an important role in organised crime, but little attention has been paid as yet to criminal families and intergenerational transmission of delinquent behaviour as well as criminal 'leadership.' This paper presents the results of an in-depth study of seven families in the south of the Netherlands that produced a leader of a criminal group in at least one generation. In almost every generation, most male and female members of these families have criminal records, but intergenerational transmission of criminal leadership has so far occurred in only two families. There is a range of risk factors that promote criminal behaviour across generations, but an important explanation is that family members select their partners and friends from their own closed and deviant subcultures, and seem to favour those who have already developed criminal track records. Apart from risk factors at the individual, family and social environment levels, criminal behaviour was also stimulated by the seven families quickly taking advantage of emerging crime markets, particularly ecstasy production and indoor cannabis cultivation from the 1990s onwards.
\end{abstract}

Keywords Intergenerational transmission - Organised crime · North-Brabant · Family · Parenting $\cdot$ Social learning

Toine Spapens

a.c.spapens@uvt.nl

Hans Moors

moors@emma.nl

1 Department of Criminal Law, Tilburg University, P.O. Box 90153, 5000LE, Tilburg,

The Netherlands

2 EMMA, Experts in Media and Society, Wijnhaven 88, 2511 GADen Haag, The Netherlands 


\section{Introduction}

The south of the Netherlands is generally considered a hotbed of organised crime (Spapens 2017). Already in the 17th and 18th centuries, large itinerant gangs resided in the province of North Brabant, and from 1830 until 1962, many inhabitants were involved in smuggling networks. Since the 1990s, the province has been considered the heartland of synthetic drugs production and cannabis cultivation in the Netherlands (Ibid). Listening to police officers, one can hear stories about decades or even centuries of family involvement in these activities.

This observation was the starting point of our study of intergenerational transmission of criminal behaviour in families that produced a leader of an organised crime group in at least one generation. We focused on two main research questions. First, can we indeed observe criminal behaviour and involvement in organised crime groups and their leadership in successive generations? Second, if so, which transmission mechanisms could explain this? In this paper we present the main findings.

We selected seven families in the south of the Netherlands and collected data on at least three generations. Our starting point was the generation which produced a criminal leader. The police established this leadership position during large-scale criminal investigations which had been completed from the second half of the 1990s to the first half of the 2000s. The selected crime entrepreneurs were born in the period from 1950 to 1965 , and became criminal leaders in the early to late 1990s. All families selected had been living in the Netherlands for at least four generations. Our data was collected from local and regional archives; the population registration database; interviews with (former) practitioners who had been involved with the families as well as information from police files.

Earlier research has addressed intergenerational transmission in a wide range of contexts, such as addiction problems, cultural capital, cognitive abilities, divorce, and entrepreneurship, to give a few examples. Within criminology, the number of studies on intergenerational transmission of delinquent behaviour is relatively small, but growing. In the United Kingdom, David Farrington can be considered a pioneer who has conducted longitudinal research since the 1970s (West and Farrington 1977; Farrington 2002). Studies of intergenerational transmission of delinquent behaviour have been conducted in a range of countries (for an overview see Eichelsheim and Van de Weijer 2018). In the Netherlands, the Transfive database was an important source for academic research. It compiles information on five generations, taking as a starting point a group of young males who were sent to a correctional facility in the early twentieth century (See Bijleveld and Wijkman 2009; van de Weijer 2014).

Studies of intergenerational transmission of criminal behaviour have mainly used quantitative approaches and focused on high-volume crimes. Almost without exception, outcomes reveal that children of parents who have been convicted run a higher risk of ending up with criminal records themselves. A meta-analysis by Besemer et al. (2017), which compares 23 datasets including 3.5 million children, shows that children with one or more convicted parents have a 2.4 times higher risk of being convicted themselves. We know that within serious and organised crime networks, families play an important role, for instance because family ties provide trust relations (van de Bunt et al. 2014). Generation studies of families involved in organised crime are almost nonexistent, however. In Italy, Ingrascì (2007) studied the role of women in 
intergenerational transmission of 'mafia values' within a Calabrian mafia family. In the Netherlands, apart from our own study, only one other has so far been conducted on professional criminals and their children in Amsterdam (van Dijk et al. 2018).

The following section first describes the analytical framework we derived from research on intergenerational transmission of delinquent behaviour. This will be followed by a description of the methodology and data sources used in this study. After that, we will present our findings on the criminal behaviour of the families across three or four generations and how these findings can be explained. The paper closes with conclusions and a discussion.

\section{Analytical framework}

Explaining why intergenerational transmission of criminal behaviour occurs is extremely difficult. Generally, delinquency is attributed to a wide range of risk factors, which in turn interact with protective factors. The extent to which these factors are transferrable from one generation to another may differ and it also depends on a range of other variables. Regarding transmission of protective factors, we still know very little. Given these limitations, we can distinguish the transfer of risk factors at the level of individual characteristics and behaviour, the family level and the social environment level. Based on our own research, we have added a fourth category: opportunity structures. We will start by briefly discussing the first three groups of risk factors, focusing on outcomes of empirical research conducted in the Netherlands.

\section{Individual level risk factors}

At the individual level, risk factors are related to genetic disposition, aggressive behaviour, substance abuse, low levels of education and problematic school careers. These factors are intertwined to some extent. There is no genetic disposition for delinquency as such, but genes may influence aggressiveness, addiction risks and intellectual capabilities (e.g. Caspi et al. 2002; Rutter 2007; Ferguson 2010; Besemer 2012). Children with parents who have been convicted for violent crimes generally run a higher risk of conviction for violence, although people who commit violent crimes are often also sentenced for other types of crime (van de Rakt et al. 2006; Besjes and van Gaalen 2008; van de Weijer et al. 2011). Abuse of alcohol and narcotic drugs may be a risk factor because addicts may commit crimes related to their addiction, such as drunk driving; to generate money, for instance through property crimes; or they may be convicted for the possession of illicit drugs. A Dutch study indeed revealed an intergenerational effect for drug-related offences (Besjes and van Gaalen 2008). However, in the Netherlands, possession of quantities for personal use is not prosecuted and drug offences thus concern trade, trafficking and production, which complicates interpreting this finding. Next, a lack of intellectual capabilities and a troublesome school career can be risk factors. Dutch research shows that the level of education of parents and children does indeed correlate, albeit rather weakly (Traag and Siermann 2011). Finally, intergenerational effects in dropping out of school are observed, but are difficult to isolate from other factors, such as poverty. 


\section{Family level risk factors}

The core family is important for the transfer of values and attitudes and, not surprisingly, researchers of intergenerational transmission have particularly focused on risk factors at the family level. To begin with, parents with criminal records might be less skilful or motivated in imposing rules on their children, or in teaching them societal values to which they do not want to adhere themselves (Farrington 2002). A related explanation is that parents actively teach their children criminal skills or at least show behaviour the younger generation will imitate. Criminal brothers and sisters may also be important in this respect (Rowe and Farrington 1997). Next, assortative mating is considered as a risk factor (Farrington 2002). Persons generally choose partners whose ideas and behaviour are similar, and individuals with a history of deviance may thus prefer spouses who do not categorically reject delinquent behaviour. However, these assumptions have been generally difficult to assess empirically.

A risk factor which has been studied more extensively is the families' stability when faced with the absence of one of the parents following a divorce or a long prison sentence, as well as stress caused, for instance, by poverty and domestic violence. In the Netherlands, children who grow up in a broken home are convicted twice as much as children who grow up with two parents, although the effect is largely unrelated to whether the father has a criminal record (van de Rakt et al. 2006; van de Rakt 2011). In criminal families, the father's absence may have positive as well as negative effects, depending on the father's behaviour or the mother's ability to manage the family on her own, for instance because of serious financial problems (van de Rakt 2011; Besemer 2012). There is also support for intergenerational transmission of poverty. In the Netherlands, $25 \%$ of children whose parents lived on social benefits were also dependent on such benefits (CBS, 2015). However, this still leaves a relatively large group living in a persistent situation of financial deprivation, which is in itself an important risk factor for criminal behaviour (see also Besemer et al. 2017). Finally, a family's bad reputation can be a risk factor. It may lead to labelling and increased police attention (Farrington 2002). Empirical studies suggest that such an effect indeed occurs (West and Farrington 1977; Besemer 2012; Besemer et al. 2013).

\section{Social environment risk factors}

Risk factors related to the broader social environment resemble family level factors, and we will therefore mention these only briefly. To begin with, membership of closed subcultures in which norms and values differ from mainstream society is considered a risk factor, particularly if members persist through the generations in seeking their partners (see above) and friends in these subcultures. Such groups may also have a negative reputation and this may result in social exclusion and labelling. Van Dijk et al. (2018) studied a group of professional criminals and their children in Amsterdam. The authors concluded that the risk of intergenerational transmission in these families was high. The children ranged in age from 19 to 33 years old and almost all male children, and about one third of the females had criminal records. One important finding was the risk of traumatisation of mothers and children, on the one hand because of domestic violence and on the other because of confrontations with violent attacks on the father. No less than six of twenty-five fathers had been murdered. Another was the observation 
of both assortative mating (for females) and assortative friendships (for males). Partners and friends often had built criminal records prior to the relationship, and sons of professional criminals were often friends of each other. Finally, the premise that poverty might explain intergenerational transmission did mostly not apply to the children. Except for those whose fathers had been murdered, which confronted the families with loss of illegal income, most children had grown up in luxurious material conditions.

\section{Methodology and data collection}

As explained above we selected 7 criminal families who have lived in the south of the Netherlands for at least three generations. The latter choice allowed to gather data from archives, but excluded immigrant families who moved to the Netherlands from the 1960s onward.

Two families have lived in rural villages and three families in one of the larger cities in North Brabant (150,000-250,000 inhabitants). A further two families reside in medium-sized towns (75,000 inhabitants). Two families can be defined as 'travellers' and most members reside in what are called trailer camps. It must be noted that such camps are nowadays permanent residential areas where people live in chalets that qualify legally as 'campers', but moving them would require at least a large crane and a low-loader. Although the Netherlands has small communities of Roma and Sinti, most travellers are of ethnic Dutch descent and only the latter were selected for this study.

Our empirical findings are based on two main sources. To begin with, we conducted extensive research of archives. According to the Archive Act, information generally becomes public after 20 years. Specific rules apply to privacy-sensitive information. Logically, information relevant to our object of study is not stored in a single archive. We searched court archives, archives of local police forces, archives of municipal and regional administrative bodies, and welfare and social security agencies, archives of religious institutions and the archive of the probation service. The main provincial archive is the Brabant Historical Information Centre, but several municipalities maintain local archives. The second part of our empirical research focused on the period from 1990 onwards. For this, we studied the files of criminal investigation cases aimed at one or more family members. Next, we interviewed current and former police officers, and staff of other investigative services (14); probation officers (4); welfare workers (3); who all had been in contact with the families selected, and experts on the history of the province of North Brabant (4) to acquire a more general perspective.

As a starting point, we reconstructed the families' composition from the population administration database, as well as archives. Criminal records were retrieved from the police criminal records database. This contains information dating back to approximately 1984. Earlier convictions were collected from the archives. Finally, we searched the media through LexisNexis, which nowadays archives Dutch newspaper publications as far back as the 1980s. Over the years, several family members have appeared in media interviews. We chose not to approach family members themselves. This choice was mainly a practical one, because access to confidential police information is allowed only under the condition that researchers do not attempt to contact any subjects involved, but safety considerations were also important. Logically, much attention had to be given to anonymising findings to the extent that individual families could not be identified. 


\section{Intergenerational transmission of delinquent behaviour: findings}

For our study of intergenerational transmission of criminal behaviour, the 'family' is defined as the core family, limited to members who were 18 years or older in 2015 . We took as a starting point the generation in which the selected criminal leader was active (generation 2) and looked at criminal records of his brothers and sisters, as well as spouses. Next, we studied the kingpin's children and their partners (generation 3). If grandchildren had been born who had reached adulthood, we also included them (generation 4). Finally, we focused on the kingpin's parents (generation 1). The general time frame for the study was 1945-2015, although in some cases members of generation 1 had been born earlier. Results are shown in Table 1.

Outcomes show high percentages of males with criminal records, across four generations. Apart from generation 1, the percentage of female family members with criminal records is also remarkably high. ${ }^{1}$ The number of adult children in generation 4 is relatively small and the picture may still improve, although the perspective does not seem to be promising. When compared to the outcomes of general studies of intergenerational transmission of delinquent behaviour, these families show much higher percentages. Women in particular have run-ins with the judicial system more often than is usually the case. If we look at organised crime, however, a pilot study amongst professional criminals in Amsterdam produced similar results (van Dijk et al. 2018). Apparently, such families are indeed 'special'.

Most members of generation 1 grew up between the 1930s and the 1950s, when North Brabant was still a poor and agricultural region, which is reflected in the type of crimes that were committed. These were predominantly property crimes (theft, fencing of stolen goods) and violent crimes, including domestic violence. In two cases, the males of generation 1 were convicted only once. Two others, however, developed a substantial career in 'traditional' crimes, but one also started to commit drug-related crimes from the early 1980 s onwards. Finally, one person was convicted for property crimes but also for illegal alcohol production and trafficking, together with two of his sons. The only female in generation 1 with a criminal record committed a substantial number of property crimes as well as domestic and other violent crimes.

The second generation grew up from the 1960s through the early 1980s. All males with criminal records committed violent crimes, sometimes even manslaughter and murder. Several cases concerned threat and extortion. Most were also convicted for property crimes, which in some cases had been committed on a large scale. One person was a member of the notorious 'Kempen gang' which emerged from the travellers' community and was responsible for several hundred ram raids in the 1970s and early 1980s. New types of crime also emerged, which partly reflected the economic development of North Brabant, such as traffic offences. Levels of seriousness increased, reflected in crimes such as trade in illegal firearms, counterfeiting and large-scale money laundering. Although the families were relatively late in exploiting the opportunities of the drug trade and production, they also became involved in this from the 1980s onwards. Most crime entrepreneurs of generation 2 largely disappeared from the police radar in the mid-1980s until they were arrested at the end of the 1990s and early

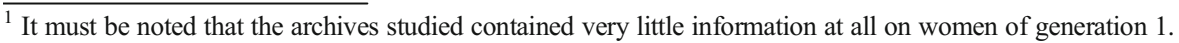


Table 1 Criminal records across generations

\begin{tabular}{lllll}
\hline & Generation 1 & Generation 2 & Generation 3 & Generation 4 \\
\hline Adult males & 7 & 18 & 29 & 6 \\
Adult males with criminal records & $5(71 \%)$ & $17(94 \%)$ & $22(76 \%)$ & $6(100 \%)$ \\
Adult females & $9^{a}$ & 12 & 23 & 4 \\
Adult females with criminal records & $1(11 \%)$ & $7(58 \%)$ & $14(61 \%)$ & $2(50 \%)$ \\
Minors & - & - & 7 & 60 \\
\hline
\end{tabular}

${ }^{a}$ In two families, women in generation 1 remarried

2000s for drug-related crimes. The women of generation 2 were convicted for property crimes and violent crimes. Most of them were sentenced only once, but several others very frequently.

Generation 3 mostly reached adulthood in the 1990s and early 2000s. Here, the focus shifts more towards drug-related crimes, both for men and women. It must be noted that female involvement in this type of crime mainly concerns two families with a relatively large number of daughters. In one of these families, half of the women were convicted more than once for drug-related crimes. Most family members stop committing minor and major property crimes after the early part of their criminal careers. Violence, however, is often persistent throughout a person's life. In generation 3, cannabis cultivation developed into a major source of illegal income, whereas in generation 2, drug trafficking (cannabis, hashish and cocaine) as well as synthetic drug production had been more prominent. In just two out of seven families, no sons or daughters had been convicted for drug crimes.

Finally, although the number of adult children in generation 4 is still relatively small, they seem to continue with types of crime similar to those committed by generation 3 . Convictions most commonly concern theft, violence and drug production and trafficking. This applies to males as well as females.

The above findings show that criminal families indeed exist. But do they also qualify as 'family businesses' that manage to maintain a leading role in serious and organised crime from generation to generation? Here the picture is less clear. Based on interviews with police officers and other sources, it is only in two families that we observe sons in generation 3 who succeeded in taking up an independent leading role in a criminal cooperative. In a third case, a daughter (generation 3) married a man who ran his own criminal operations. However, because the couple divorced before children were born, this transmission link was severed.

We can explain these findings in three ways. To begin with, it proved difficult to succeed a kingpin father because such a father continued engaging in criminal activities far beyond retirement age. In two families, sons in generations 2 and 3 cooperated closely with their fathers, but kept to an assisting role. In the two cases where the son operated his own criminal group, he had developed this role without much fatherly support and with friends of his own generation. In these cases, fathers and sons also operated in different illegal markets: the fathers in cocaine and synthetic drugs, and the sons mainly in cannabis cultivation. A conversation between father and son which was recorded by the police is illustrative. The father tried to give his son advice on how to 
run his business and perhaps take over his father's contacts, which would enable the latter to slowly head for calmer waters, but the son was not interested. 'I know perfectly well what I am doing and I do not need your advice. Furthermore, I do not want to work with your business partners because they are old guys to whom I cannot relate.'

Second, being a crime entrepreneur requires organising skills and a clear head. In some cases, the next generation simply lacked the capabilities to run a criminal group, or was too often incapacitated by drug and alcohol abuse. It must be noted that 'Dutch style' organised crime mostly revolves around the trade in and production of narcotic drugs, compared for instance to southern Italy, where mafia clans' power is primarily grounded in territorial domination and crimes such as extortion and fraud with government contracts (Spapens 2013; Dickie 2013). The latter require for instance a violent reputation and relations with corrupt local officials. In this situation of local embeddedness transmission of leadership may be easier. Instead, the most successful Dutch criminal leaders must build their cooperatives from scratch and depend heavily on social skills and their ability to run things whilst avoiding the use of violence as much as possible. As noted above, fathers apparently experience difficulties in transferring such skills to the next generation, whereas the alternative of sending them to a 'crime university' does not exist.

Third, Dutch women almost never take up managing positions within the criminal underworld and crime entrepreneurs who only had daughters were unable to pass on their leading role to the next generation. Women do play an important role in Dutch criminal networks but examples of women leadership are rare or temporary, for example when their husbands serve a short prison sentence. In most families we observed highly conservative views on the role of women in general, although this certainly does not imply that these are also put to practice. For example, extramarital activities are not just common for the men, but also for many of the women.

\section{Intergenerational transmission of delinquent behaviour: Explanations}

In "Analytical framework" section, we distinguished risk factors for intergenerational transmission of delinquent behaviour at four levels: individual, family, social environment and criminal opportunity structures. This section discusses these factors in the light of the empirical information we were able to obtain.

\section{Individual level risk factors}

At the individual level, we were unable to establish the role of genetic factors. However, aggressive and violent behaviour is a risk factor that applies to all generations of the seven families. Women hardly differ from men. Violence is applied functionally towards 'outsiders' and officials from different institutions, with the aim of receiving favours, but also to be left in peace. The former may, for instance, refer to 'persuading' a social housing association to assign a house or a trailer to a family member. The latter may involve threatening a municipal education officer who enquires why a son or daughter does not show up at school. Dysfunctional violence, however, is just as common in these families. This may take the shape of domestic violence, but also of feuds either within or between families, which sometimes end in murder. Generally, 
these families seem to view violence as an acceptable strategy to solve disputes. The risk of intergenerational transmission of violent behaviour is substantial. On the one hand, dysfunctional aggressiveness may traumatise children, but on the other, they learn that at least from a short-term perspective, it intimidates most outsiders sufficiently to produce the desired outcome.

Substance abuse also appears to be common from generation 2 onwards, although it is difficult to draw the line between recreational and problematic alcohol and drug use. The first generation generally lacked the financial means to drink heavily throughout the week and the use of illicit drugs was at the time as good as unknown. Amphetamine may have been an exception, but this drug was legal until 1975. This changed with generation 2, when some members became involved in drug trafficking and production, whereas several others suffered addiction problems. Violent retribution and the collapse of family cohesion sometimes followed the death of an addicted family member, for example when another family member had supplied the drugs. Later generations, although no strangers to alcohol and drugs, mostly kept their use within manageable proportions.

Next, low levels of education as well as dropping out of school appear as an intergenerationally transferrable risk factor. However, it is difficult to attribute this directly to intellectual capabilities. Until the 1960s, most children of working-class families, and particularly girls, were forced to go to work after completing primary or, at best, secondary education, because the family needed the extra income. The situation in the seven families was no different, and to some extent even worse. Almost no members of generations 1 and 2 succeeded in completing secondary or professional education. Archives regularly present indications of low literacy and even illiteracy as well as school careers terminated prematurely. Most crime entrepreneurs hardly spoke a foreign language, except for one who had trained as a school teacher. We were unable to find systemic information on generations 3 and 4 . In some families, these generations did not seem to fare much better, although the general level of education did increase from primary to secondary levels and some completed professional education. Generally, female family members appear to do better at school than their brothers (see also van Dijk et al. 2018). It is, however, important to note that low levels of formal education do not imply a lack of skills required in the criminal underworld. Most crime entrepreneurs had a knack for mental arithmetic and a more than excellent memory, as well as sensitive antennae for trade opportunities. More commonly, family members were experienced in applying methods to screen off their activities from the authorities. Lack of language skills did not prevent crime entrepreneurs from trading ecstasy pills all over the world.

\section{Family level risk factors}

Our study shows that the seven families distance themselves from their institutional environment and can be viewed as closed entities, particularly towards authorities who want to influence their behaviour. Consequently, we know little about parenting skills. In a few families, the parents were clearly unable to run a structured household, but we do not know whether this affected their children's criminal behaviour.

Assortative mating emerges from our data as a crucial risk factor. Family members almost always chose partners from their own subculture, although in generation 3 we 
also observed some relationships with individuals of Turkish, Moroccan and SoutheastEuropean descent. More importantly, however, the women all seemed to favour partners who at the time of marriage had already achieved a criminal track record. The women not only accepted this, but often started to contribute to their husbands' illegal activities.

Next, the families cannot be considered stable entities. We often observed tensions caused by divorce, regular absence of the father of the family, because of his criminal activities as well as stints in detention, and traumas caused by threats and violence. On the one hand, ideas about marriage and the role of women are extremely traditional, whereas on the other, extramarital activities of both men and women are commonplace. Particularly in generations 2 and 3, family structures often become a complex tangle because of broken relationships and families composed of children who stem from different combinations of partners. In one case, a man even seemed to have lost track himself, mentioning a different number of children in an interrogation from that recorded in the population registry. We were unable to establish the effect on children's behaviour of their fathers being absent because of detention. The same applies to the effects of the general stress and risks that come with a life of crime. At the time of writing, all crime entrepreneurs in generation 2 were alive, although in some cases they had survived attempts on their lives.

In the search for explanations for intergenerational transmission of crime, an obvious assumption is that children learn from their parents, or at least try to imitate their behaviour. As mentioned above, we did not explicitly observe an 'education' in how to be a crime entrepreneur. In cases in which the sons cooperated with their fathers, it is logical that they were taught the tricks of the trade in practice, but so far this has not led them to setting up their own businesses. Given the fact that until now, only two sons run a criminal group independently from their fathers, it seems that the older generation setting an example, as well as possible targeted educational efforts, did not produce much of a result. However, we may assume that growing up in a family in which crime is accepted as a way of life, and where illegal activities contribute functionally to wealth and independence, does have an educational influence. In practice, there are many ways to learn and further research is needed within the context of criminal families.

Next, we looked at the risk of labelling members of notorious families. On the one hand, the names of criminal families are indeed widely known within their communities and logically also by the authorities. Most families have had a bad reputation for decades. On the other hand, such knowledge is usually limited to the local level and even then, not all police officers know all family members by sight. However, there were indications that members of criminal families benefit from their reputation, for instance because victims who ended up in bar fights with them did not dare to report this. The same applies to witnesses who are afraid to talk when a member of a criminal family is involved. In other words, a label may cause more police attention, but it also helps to avoid being convicted.

Finally, poverty did obviously play a role in the first generation and to some extent also in the second. These people grew up either in rural villages, in not very affluent city neighbourhoods or in large trailer parks in a period when economic prosperity in North Brabant was slowly increasing, but life was still anything but luxurious. We have no indications that the seven families were at that time already wealthy exceptions. However, things changed from the 1980s onwards, when narcotic drugs became the 
focal point of illegal activities. Members of generation 2 who developed a key position in drug production and trafficking acquired substantial wealth in the 1990s, and the third and fourth generations grew up in favourable material circumstances. Even when substantial prison sentences were imposed on the crime entrepreneurs of generation 2, it does not seem to have had much effect on their wives and children, except in two families. In one case, the mother was mentally unstable and was sent to prison for helping her husband to prepare an assassination, with the result that her children were put into the custody of grandparents. In the other family, none of the members were able to maintain a steady flow of substantial illegal income or to spend their money sensibly.

\section{Social environment risk factors}

Our study shows that all seven families are part of subcultures where 'authorities' of all sorts are viewed as adversaries and semi or fully illegal activities considered to be acceptable survival strategies. The seven families share hostility towards any type of authority, ranging from government officials to bosses at work, although most only want to run their own business anyway. A common sentiment is that 'no one determines what your day will look like'. Another similarity is the all-important role of internal loyalty. It is only other members of the extended family who can be fully trusted in an otherwise hostile world. The importance of subculture is underlined by the fact that almost all friendships are also with insiders. Family members who succeed in breaking out of - or avoiding - a life of crime almost always distance themselves from their social environment, for instance by leaving the neighbourhood or the trailer camp, and they often choose a non-criminal partner from 'outside' (see also Adjiembaks 2018).

From a perspective of intergenerational transmission, this mechanism of 'assortative' choice of partners and friends is crucial because it repeats itself in every generation. Although not all friendships are deviant, crime entrepreneurs do often select members of their criminal groups from a pool of trusted family members and friends (Spapens 2006; 2018). Furthermore, in extended families that share a common culture, every generation only needs to produce a few members who have the talent for organising complex illegal activities, because it allows others to benefit in less prominent roles. In one family, for example, a member was able to set up cannabis nurseries because his nephew could export several hundred kilos every week. It also enabled him to sell wholesale quantities of ecstasy pills - unfortunately for him to an undercover police officer - because another member of his extended family ran a synthetic drugs laboratory.

Finally, labelling may also occur at the level of communities, but also with negative as well as positive effects. In our study, particularly traveller families experienced stigmatisation, even by fellow criminals. At the same time, travellers succeeded in presenting themselves as victims of government policies aimed at integrating them into mainstream society, which mostly had detrimental effects (Khonraad 2000). To some extent, inhabitants of poor neighbourhoods have also depicted themselves as victims, in this case of neo-liberal policies which caused job losses (Tops 2018). Indeed, our study shows that for a long time, local authorities tended to approach these communities with a feeling of guilt, and were prone to leniency towards deviant behaviour and tax evasion, for instance, which was of course exploited to the full. 


\section{Opportunity structures as risk factors}

Finally, our empirical data show how the seven families managed to exploit new criminal opportunities that arose over the years, particularly regarding narcotic drugs. Until the 1980s, most families were limited to committing property crimes and were primarily a nuisance because of their members' anti-social behaviour. Only two families were already involved in what we now consider organised crime, one producing illegal alcohol, which is sometimes seen as a direct forerunner of synthetic drugs production, and the other as members of the Kempen gang, which committed many, often violent, robberies. In the 1980s, narcotic drugs, first cannabis and hashish, and later cocaine, enabled several families to expand their criminal activities. We were unable to acquire information on how these families developed contacts with drug traffickers. Generally, networks involved in the drug trade first emerged in Amsterdam but other parts of the Dutch criminal underworld soon joined in this profitable new business. Contacts probably stemmed from the days in which the southerners sold stolen and smuggled goods there, and from 'recreational' activities in, for example, the Red-Light District. Amsterdam-based criminals were apparently looking for investors in large drug shipments and set up joint ventures with travellers from North-Brabant. By the end of the 1980s, southern criminals had established their own direct contacts with Pakistani suppliers, for example (Fijnaut 1995).

In the 1990s, synthetic drugs production and particularly ecstasy presented generation 2 with the opportunity to expand their business to the international stage. Ecstasy production again first started in the Amsterdam area, but the south also numbered more than enough chemists who were quick to learn. This time, buyers from all over the world came to the Netherlands to find the excellent quality Dutch ecstasy. In these circumstances, it is no surprise that even criminals who hardly spoke a foreign language had little trouble selling their merchandise. Apart from one family, all the families included in our study became involved in wholesale ecstasy trade and production. Finally, in the early 1990s, another criminal opportunity presented itself when indoor cannabis cultivation methods were introduced. Except for two individuals, the criminal entrepreneurs in generation 2 ignored cannabis, but for the two sons in generation 3 who became independent leaders of their own criminal groups, this was the market on which they focused. More generally, setting up a cannabis nursery was and is a low-threshold and relatively low-risk money maker for any member of the families we studied.

\section{Conclusion and discussion}

The results of our study show that families who are in at least one generation involved in organised crime can indeed be considered criminal families when we look at their members' criminal records. In families that have been actively involved in organised crime, even if this is limited to just one generation, intergenerational transmission of delinquent behaviour is a much larger problem than has been found in studies based on general criminal records. This particularly applies to the criminal behaviour of women, even if we consider that they partly commit crimes on behalf of their partners, such as hiding an illegal firearm or money laundering. This finding is also important, because from the literature it follows that children with a convicted mother run a higher risk of 
being convicted than those with only fathers with criminal records. If both parents have criminal records, the risk of intergenerational transmission increases even more (Besemer et al. 2017). Criminal families can therefore be considered an important object of research.

Our study also shows that transmission of organised crime leadership is less evident. In the Dutch criminal underworld, where organised crime is mainly associated with trading and producing narcotic drugs, it is apparently difficult to run these activities as a family business. Here, we have presented several explanations but further research is necessary, especially a cross-national comparative study. Perhaps it is less difficult to transfer leadership when it comes to classic mafia-style crimes such as extortion (which is less demanding in terms of skills) and racketeering (because running a legitimate business can be learned in regular education). Why do successful Dutch criminals not send their children to expensive international schools to guide them to high-status legitimate jobs and a social network in the upper class, for example?

The present study underlines the complexity of qualitative and quantitative research of intergenerational transmission of crime, including organised crime. Many risk factors may contribute to criminal behaviour as such and for each of these, other factors may determine whether the next generation will end up displaying similar red flags. Several risk factors, such as labelling or parents who actively teach their children criminal skills, remain difficult to assess. However, our study showed that some risk factors can be identified more clearly. Particularly the fact that members of these seven criminal families seem to favour partners and friends with criminal records, who mostly originate from their immediate and closed social circles, emerges as an important explanation for intergenerational persistence of criminal behaviour. In the context of organised crime, opportunity structures also play an important role. Without the emergence of the drug trade and particularly ecstasy production, generation 2 could still have continued committing minor and major property crimes, but would not have been able to develop international criminal relationships, let alone gain as much wealth as they did. For generations 3 and 4, cannabis cultivation presented itself as a highly profitable, and at the same time easily accessible, illegal activity. The reasons why they engaged in these activities, may however be different than for generations 1 and 2, for instance not because of poverty, but to maintain the material lifestyle in which they were raised. It is also important to broaden the family lens from core to extended families, because these play an important role in providing the 'pool of criminal human capital' that enables the next generation to continue its illegal activities.

A highly relevant final question is how to disrupt transmission of criminal behaviour in these families. On the one hand, repression and convictions hardly broke the chain of intergenerational transmission of criminal behaviour. On the other, preventative approaches in the shape of social support and attempts to guide family members to jobs and education have also failed to produce many results. Our families have over the years perfected a range of strategies to resist outsider interventions, as well as to exploit institutions to their advantage. Even for family members who want to choose a different path, it is difficult to escape from the closed deviant subcultures of which they are a part, without completely breaking all ties, at least for several years. In the Netherlands, criminal families are currently high on the agenda in many municipalities, and projects combining hard and soft approaches have been started in several places. It is, however, clear that 'quick fixes' do not exist and that attempts to normalise the behaviour of these families requires a long-term perspective. 
Funding This study was funded by Politie en Wetenschap, the Netherlands.

Grant number PW/OC/2014/19.

\section{Compliance with ethical standards}

Ethical approval All procedures performed in studies involving human participants were in accordance with the ethical standards of the institutional and/or national research committee and with the 1964 Helsinki declaration and its later amendments or comparable ethical standards.

Informed consent Informed consent was obtained from all individual participants included in the study.

Conflict of interest The authors declare that they have no conflict of interest.

Open Access This article is distributed under the terms of the Creative Commons Attribution 4.0 International License (http://creativecommons.org/licenses/by/4.0/), which permits unrestricted use, distribution, and reproduction in any medium, provided you give appropriate credit to the original author(s) and the source, provide a link to the Creative Commons license, and indicate if changes were made.

\section{References}

Adjiembaks S (2018) (On)gemerkt bijzonder. In: Levensverhalen van resisters en de betekenis van uitblijven van een criminele carrière. Heerlen, $\mathrm{PhD}$-thesis. Open University

Besemer S (2012) Intergenerational transmission of criminal and violent behaviour Cambridge. PhD Thesis

Besemer S, Farrington D, Bijleveld C (2013) Official bias in intergenerational transmission of criminal behaviour. Br J Criminol 53:438-455

Besemer S, Ahmad SI, Hinshaw SP, Farrington DP (2017) A systematic review and meta-analysis of the intergenerational transmission of criminal behavior. Aggress Violent Behav 37:161-178

Besjes G, van Gaalen R (2008) Jong geleerd, fout gedaan? Bevolkingstrends 2:23-31

Bijleveld C, Wijkman M (2009) Intergenerational continuity in convictions: a five+ generation study. Crim Behav Ment Health 19:142-155

Caspi A, McClay J, Moffitt TE, Mill J, Martin J, Craig IW (2002) Role of genotype in the cycle of violence in maltreated children. Science 297:851-854

CBS (2015) CBS: Wie opgroeit in een uitkeringssituatie heeft later bovengemiddeld vaak een uitkering. http://www.cbs.nl/nl-NL/menu/themas/arbeid-sociale-zekerheid/publicaties/artikelen/archief/2015/2015wie-opgroeit-in-eenuitkeringssituatieheeftlater-bovengemiddeld-vaak-een-uitkering-wm.htm

Dickie J (2013) Mafia Republic. Hodder and Stoughton, London

Eichelsheim V, Van de Weijer S (2018) Intergenerational continuity of criminal and antisocial behaviour. Routledge, London and New York

Farrington D (2002) Developmental criminology and risk-focused prevention. In: Maguire M, Morgan R, Reiner R (eds) The Oxford handbook of criminology. Oxford University Press, Oxford

Ferguson C (2010) Genetic contributions to antisocial personality and behavior: a meta-analytic review from an evolutionary perspective. J Soc Psychol 150(2):160-180

Fijnaut, C (1995) Georganiseerde criminaliteit in Nederland: de rol van autochtone criminele groepen. Kamerstukken II, Vergaderjaar 1995-1996, 24 072, nr. 17

Ingrascì O (2007) Women in the 'Ndrangheta: the Serraino-Di Giovine case. In: Fiandaca G (ed) Women and the mafia. Springer, New York, pp 47-52

Khonraad S (2000) Woonwagenbewoners, burgers in de risicomaatschappij. Uitgeverij Jan van Arkel, Utrecht Rowe D, Farrington D (1997) The familial transmission of criminal convictions. Criminology 35:177-201

Rutter M (2007) Gene-environment interdependence. Dev Sci 10:12-18

Spapens T (2006) Interactie tussen criminaliteit en opsporing. Intersentia, Antwerp and Oxford

Spapens T (2013) Dutch crime networks. In: Bruinsma G, Weisburd D (eds) Encyclopedia of Criminology and Criminal Justice. Springer, New York, pp 1211-1219 
Spapens T (2017) North Brabant: a brief history of a hotbed of organised crime. In: Antonopoulos G (ed) Illegal entrepreneurship, organized crime and social control. Springer, Switzerland, pp 57-72

Tops P (2018) Een ongetemde buurt: Achterstand, ondernemingszin en criminaliteit in een volksbuurt. Uitgeverij Balans, Amsterdam

Traag, T \& Siermann C (2011) Zo vader zo zoon, zo moeder zo dochter? Een onderzoek naar de intergenerationele overdracht van onderwijsniveau en -richting. CBS, Sociaaleconomische trends $4 \mathrm{e}$ kwartaal: 26-29

van de Bunt H, Siegel D, Zaitch D (2014) The social embeddedness of organized crime. In: Paoli L (ed) The Oxford handbook of organized crime. Oxford University Press, Oxford, pp 321-339

van de Rakt, M (2011) Two Generations of Crime: The Intergenerational Transmission of Criminal convictions over the Life Course. Nijmegen, Phd Thesis

van de Rakt M, Nieuwbeerta P, de Graaf N (2006) Zo vader, zo zoon? De intergenerationele overdracht van crimineel gedrag. Tijdschr Criminol 48(4):345-360

van de Weijer S (2014) The intergenerational transmission of violent offending. PhD-thesis VU University, Amsterdam

van de Weijer S, Bijleveld C, Blokland A (2011) De overdracht van gewelddadige delinquentie tussen drie generaties mannen. Tijdschr Criminol 53(3):244-259

van Dijk M, Kleemans E, Eichelsheim V (2018) Children of organized crime offenders: like father, like child? An explorative and qualitative study into mechanisms of intergenerational (dis)continuity in organized crime families. European Journal on criminal policy and research:1-19. https://doi.org/10.1007/s10610018-9381-6

West D, Farrington D (1977) The delinquent way of life, London

Publisher's note Springer Nature remains neutral with regard to jurisdictional claims in published maps and institutional affiliations. 